\title{
GENDER DISCRIMINATION IN BRAZILIAN LABOUR MARKET AND THE ROLE OF THE PRIVATE SECTOR
}

\section{DISCRIMINAÇÃO DE GÊNERO NO MERCADO DE TRABALHO BRASILEIRO E O PAPEL DO SETOR PRIVADO}

\author{
Irene Pietropaoli ${ }^{1}$ \\ Narciso Leandro Xavier Baez ${ }^{2}$
}

\begin{abstract}
The objective of this paper is to discusses gender discrimination in the labour market in Brazil and understand the role that the private sector plays in both sustaining and fighting gender inequality and the wage gap. It does so through the analysis of main problems and challenges for the achievement of full gender equality. It is a study in the field of law, economics, and social science. The paper first reviews the history of gender equality in Brazil, highlighting both current problems and progresses, in particular in the area of legal protection of female workers. It then discusses current gender inequality issues and wage gaps in the workplace in Brazil and analyses the reasons for the persistence of such inequality. Finally, the paper discusses the role of the private sector in both sustaining gender discrimination and promoting gender equality. This paper acknowledge progress in the area of gender equality achieved in Brazil in the past two decades, but it considers that discrimination is the key persistent issue that needs to be addressed to completely eradicate this problem. In particular, special attention should be given to the role of the private sector - something that has been so far overlooked in Brazil.
\end{abstract}

Keywords: 1) human rights; 2) gender discrimination; 3) gender pay gap; 4) labour market; 5) business and human rights.

\section{RESUMO}

O objetivo deste artigo é discutir a discriminação de gênero no mercado de trabalho no Brasil e compreender o papel que o setor privado desempenha na sustentação e no combate à desigualdade de gênero e à disparidade salarial. Isso é feito através da análise dos principais problemas e desafios para o alcance da plena igualdade de gênero. É um estudo no campo do direito, economia e ciências sociais. $\mathrm{O}$ artigo primeiro faz uma revisão da história da igualdade de gênero no Brasil, destacando os problemas atuais e os avanços, em particular na área de

\footnotetext{
${ }^{1}$ Reino Unido. E-mail: irene.pietropaoli@gmail.com

${ }^{2}$ Chief Academic Officer at the "Excellence Centre in Law" at "Universidade do Oeste de Santa Catarina". Holds a Ph.D. in Fundamental Rights' Effectiveness Mechanisms, from "Universidade Federal de Santa Catatina"; a doctorate degree in Fundamental Rights and Contemporary Rights with a foreign trainee scholarship (PDEE Capes) at the Centre for Civil and Human Rights (Notre Dame University, Indiana, USA, from February 2011 to July 2011); a LL.M degree in Public Law (UNESA); a graduation degree in Civil Procedure and has been working as a Federal Judge (4th Region) since 1996. Universidade do Oeste de Santa Catarina - Brasil. Lattes: http://lattes.cnpq.br/9838220248265216 E-mail: narciso.baez@gmail.com
} 
proteção legal das mulheres trabalhadoras. Em seguida, discute as questões atuais de desigualdade de gênero e disparidades salariais no mercado de trabalho no Brasil e analisa as razões para a persistência de tal desigualdade. Finalmente, o artigo discute o papel do setor privado tanto na sustentação da discriminação de gênero quanto na promoção da igualdade de gênero. Este artigo reconhece os avanços na área de igualdade de gênero alcançados no Brasil nas últimas duas décadas, mas considera que a discriminação de gênero é a questão-chave persistente que precisa ser tratada para erradicar completamente esse problema. Em particular, atenção especial deve ser dada ao papel do setor privado - algo que até agora tem sido esquecido no Brasil.

Palavras-chave: 1) direitos humanos; 2) discriminação de gênero; 3) disparidade salarial de gênero; 4) mercado de trabalho; 5) negócios e direitos humanos.

\section{INTRODUCTION}

Women in Brazil receive a lower salary than men do, regardless their qualification or work hours. In 2018, Brazilian women earned on average 20.5 per cent less than men (AGÊNCIA IBGE, 2019). Women in high positions suffer an even higher pay gap (ARAÚJO, 2011, p. 91-92). Women not only earn less than men, but also have difficulties entering the workplace. In 2017 in Brazil, 78 per cent of men hold paid jobs, compared with only 56 per cent of women (ILO, 2017). But staying at home is often not the woman's choice. An International Labor Organization (ILO)'s survey shows that the vast majority of women in Brazil would like to have a formal job (ILO, 2017).

Brazil has achieved significant economic growth over the past two decades, but is also notable for its remarkable inequality. In 2017, the US Central Intelligence Agency reports a Gini Index of 49.7 - the $19^{\text {th }}$ highest in the world (CIA, 2017). High levels of inequality appear to be closely linked to issues of gender and race, as the income of women and non-whites is ranked at the end of income distribution (NOPO, 2012). Gender inequality in Brazil is characterized by inequality, lower female salaries and limited social protection (WAJNMAN and NETO, 2000). Brazil has historically high participation rates for men and women, as well a relatively low unemployment rate (OECD, 2017). But inclusiveness is one of the areas in need of substantial improvement. Gender gaps in access to formal employment and market income still persist in Brazil. Compared to men, women have always occupied less important jobs and secondary functions. The unemployment rate for women consistently exceeds that of men by an average of 4-5 per cent; the gap is up to twice as high for those aged 15-24. In the UN Gender 
Inequality Index of 2016 Brazil ranks $79^{\text {th }}$ out of 187 countries, with a score of 0.509 (UNDP, 2016). The 2017 World Economic Forum ranks Brazil $119^{\text {th }}$ out of 144 countries in relation to wage equality for similar work (WORLD ECONOMIC FORUM, 2017).

A number of causes leading to gender inequality have been examined in academic literature and politics, but often the role of the private sector in contributing to discrimination has been overlooked. This paper discusses gender discrimination in the workplace in Brazil, through the analysis of main problems and challenges for the achievement of full gender equality. Section I reviews the history of gender equality in Brazil, highlighting both current problems and progresses, in particular in the area of legal protection of female workers. Section II discusses current gender inequality issues and wage gaps in the workplace in Brazil and analyses the reasons for the persistence of such inequality. Section III argues that the persistence of gender discrimination is the main cause of labour-market inequality. Finally, Section IV discusses the role of the private sector in both sustaining gender discrimination and promoting gender equality.

\section{LEGAL PROTECTION OF FEMALE WORKERS IN BRAZIL}

In addition to inserting women into politics ${ }^{3}$ and protecting them from domestic violence $^{4}$, gender discrimination in Brazil has demanded regulatory interventions, affirmative action and other measures for the inclusion of women in the labour market in equal conditions as men (CAVALCANTI, 2006). Women's constitutional political rights arose in 1934 when they started voting. The 1916 Brazilian Civil Code considered the man as the head of the conjugal society - head of the household, in charge of managing the home and marital assets, and responsible for managing his wife's private goods and authorizing her to work. ${ }^{5}$ He could also decide whether a woman could live in another home and could claim marriage annulment in case of finding she was not virgin. ${ }^{6}$ Moreover, the law considered women to lack capacity to make decisions regarding civil life - they depended on their husbands for any civil act. Until the end of the 1970s women could not work in a series of jobs, as they were considered not

\footnotetext{
${ }^{3}$ Law no. 9.100 of 29 September 1995.

${ }^{4}$ Law n. 11.340/2006 of August 2006.

${ }^{5}$ Article 233, Law 3.07 of 1 January 1916.

${ }^{6}$ Ibid., Article 178.
} 
fully able to do so (CAVALCANTI, 2006).

In 1984, the National Congress ratified the UN Convention on the Elimination of All Forms of Discrimination against Women (CEDAW), but with a reservation regarding family law, specifically keeping the man as the head of conjugal society. The 1988 Federal Constitution established equality for men and women regarding rights and obligations. In 1994, six years after the Constitution promulgation, discriminatory provisions were removed from the Civil Code. The first affirmative action measures to favour women followed in 1995. Brazil signed an international agreement to enforce affirmative action measures to set quota system, legal measures, and tax credits, all to reduce gender inequality, during the 1995 Fourth World Conference on Women, in Beijing (DIAS, 1998).

During the 'Vargas Era', between 1930 and 1945, the legal emancipation of women and maternity protection in Brazil advanced, legitimating the concern for equal labour rights for men and women, as well as the fight against discrimination in employment. The constitutional reform of the military regime in 1967 included the prohibition on the employer to adopt admission criteria based on gender, skin colour and marital status. Brazil signed the International Labour Organisation (ILO) Convention No. 111 in 1968 and committed to fight discrimination and promote equality in labour conditions. The enactment of the 1988 Federal Constitution, based on the universalization of social rights, provided a legal guarantee of equality for men and women, with special emphasis on the labour sphere (TAMARINDO DA ROCHA and WEISHAUPT PRONI, 2018). The Constitution guarantees in its article 5(I) the equality of rights and obligations between men and women, prohibiting difference in salaries, the exercise of functions and criteria of admission on the grounds of sex, marital status, age and colour.

Since then, public policies have been created to combat discrimination and to prevent female labour force from being segregated or discriminated (LAVINAS, 1996). The protection of women's work in Brazil is associated with the evolution of labour laws and the performance of public institutions that should ensure its effectiveness, such as the Ministry of Labour and Employment and Labour Courts (BARROS, 1995; CALIL, 2000; MOEHLECKE, 2002). Labour legislation began to encompass a series of obligations concerning gender equality and protection of women's work (LOPES, 2006). Among other advances, articles that authorized the husband's interference in a woman's employment contract (Law 7.855/89) were repealed. Since 1995, Brazil prohibited requiring pregnancy certificates, sterilization exams, and other 
discriminatory acts when hiring or maintaining women in their jobs (CAVALCANTI, 2006). ${ }^{7}$ Another significant achievement occurred with Law 11.770 of 2008, which introduced the optional extension of maternity leave from 120 to 180 days. Brazil also has laws prohibiting gender discrimination in pay, professional training, and career advancement. ${ }^{8}$

Currently, policies for women in Brazil are guided by the National Plans of Policies for Women (NPPW) 2013-2015. The NPPW was elaborated within an unprecedented historical and social context in Brazil, governed at the time for the first time by a woman, and part of a scenario of women's demands to combating of violence against women, the construction of day-care centres and the pursuit of equal salaries between men and women. The NPPW (2013-2015) is organized in ten chapters, the first of which being 'Equality in the labour market and financial autonomy'. This first chapter reaffirms the importance of the continuity of policies for financial autonomy and equality between men and women in Brazil, with emphasis in the public labour market. Such policies aim at reaching financial independence by means of professional training for women to work in rural and urban productive sectors, as well as the access to the labour market. This chapter has as objective 'to promote equality in the labour market and the financial autonomy of women from the city, the countryside and forest areas, considering the inequality between men and women, the inequality of races, ethnicity and social classes, and developing specific actions that contribute to the elimination of the unequal gender division in the labour market, with emphasis in policies of eradication of poverty and valorisation of the women's participation in the development of the country (PRESIDÊNCIA DA REPÚBLICA DO BRASIL, 2013, p.14). The combination of these legal and policy measures has achieved some progress over the years, but Brazilian women currently still suffer inequality in the labour market.

\section{GENDER INEQUALITY IN THE LABOUR MARKET AND WAGE GAP}

The past two decades have seen changes in legislation and social norms, which have led to declining gender disparities (LIU et al, 2013, p. 802). In relation to gender inequality in the labour market a number of advances have occurred. Now women made for nearly 43 per cent of Brazil's labour force (WORLD BANK, 2017a). In the last decades, the female participation

\footnotetext{
${ }^{7}$ Law no. 9.029 of 13 April 1995.

${ }^{8}$ Law no. 5.452 of 1 May 1943.
} 
in the formal employment and the number of women in professions that require a diploma of higher education has increased. In the 1980s, the percentage of women with a formal contract was much lower than that of men. Since then, this has changed, albeit slowly. According to data from the Ministry of Labour and Employment, the insertion of women in the institutionalized labour market after the 1988 Constitution increased. Women participation in the workforce has risen by 17 per cent in 20 years: it was 37.4 per cent in 1995 and rose to 43.7 per cent in 2015 (KNAPP, 2015; (TAMARINDO DA ROCHA and WEISHAUPT PRONI, 2018). Professions that traditionally were dominated by men, such as law, medicine, and engineering, are becoming more balanced in terms of gender, and some already have more women than men. Currently, women work also in activities previously intended only for men, such as public transport, and military careers (TAMARINDO DA ROCHA and WEISHAUPT PRONI, 2018). Reports indicate a significant improvement in Brazilian women's participation in the sciences. In a 2018 study on gender in the global research landscape, Brazil stands out for its progress (ELSEVIER, 2018). The proportion of women who publish scientific articles rose by 11 per cent in Brazil over the past 20 years. Brazilian women now publish 49 per cent of the country's scientific scholarly articles, approaching gender parity in one of the fields that has historically left women behind (SIMS, 2017).

Currently, the educational attainment of women in Brazil is higher than that of men. In one study, the Ministry of Education and the Instituto Nacional de Estudos e Pesquisas Educacionais Anísio Teixeira found that in 2001 Brazilian women had attained an average of 6.2 years of education whereas Brazilian men had attained an average of 5.9 years (INEP/MEC, 2004). Illiteracy rates for women aged 15 years and older fell from 20.3 per cent in 1991 to 13.5 per cent in 2000 and 9.8 per cent in 2008 (CANUTO, 2013). The share of the female labour force with tertiary education increased from 7.4 per cent in 1992 to 11.9 per cent in 2008, and now is higher than male labour force (AGÉNOR and CANUTO, 2013; FERDI 2012b). Brazilian women are now generally more educated, with female participation in tertiary education significantly exceeding male participation.

Despite women's higher educational attainment and progress in labour participation and occupational segregation, however, the Brazilian labour market remains characterized by a clear scenario of inequality of opportunities between men and women. Despite the introduction of technological innovations and the adoption of new methods of work organization in the 1990 s, the majority of the female labour force in formal employment continues to be allocated 
to routine and low-skilled tasks (NEVES, 2000). Despite significant improvements in the national labour market in the 2000s, and the adoption of programmes focused on gender equality, a significant portion of women remain in a situation marked by precarious work, usually in low productivity activities such as personal and domestic work (LEITE, and SALAS, 2014). Even women who obtain employment with a formal contract, often receive lower wages than the men, even if they have equivalent or higher degree of education (PRONI and LEONE, 2013). There are disparities as well in rise to senior management positions in Brazil - men are more likely to occupy such positions. Although the sexual division of professional work is changing and women are starting to occupy higher qualified professions, discrimination continues to generate unequal conditions. Women have started to achieve a few leadership positions, but men still dominate in managerial roles, particularly in the private sector (TAMARINDO DA ROCHA and WEISHAUPT PRONI, 2018). Most women face invisible barriers ('glass ceiling') in the labour market, especially in large corporations, and face difficulties in gaining prominent positions and greater responsibility.

The wage gap has slowly reduced over time. Women perceived 53.1 per cent of men's salary in 1980 (KNAPP, 2015; BRUSCHINI et al, 2011). Yet, Brazilian women workers earn less than men despite their education level is higher (HRW, 2018). In 2018, women in Brazil earned 20.5 per cent less than men on average, a narrower gap than the previous year - in 2017 the gender pay gap was 21.7 per cent - but still wider than the industrialized world average (AGÊNCIA IBGE, 2019). Progress is happening, but at a slow pace. As Human Rights Watch reported 'at the current snail's pace, Brazilian women with formal jobs will receive the same wages as men only in 2083' (HRW, 2018). A woman's hour of work is still worth a fifth less than that of a man. The gap is greater in the private sector: in 2015 women received only 66.1 per cent of the average male remuneration (TAMARINDO DA ROCHA and WEISHAUPT PRONI, 2018). The gap is especially noticeable for workers with higher levels of education (LAZZARETTI et al, 2013). The Labour Ministry data shows that 60 per cent of employees with a university degree are women, but their employers paid them 36 per cent less than men with the same educational level (O GLOBO, 2018). What are the reasons for such persistent gender inequality and pay gap in Brazil?

\section{PERSISTENCE OF GENDER DISCRIMINATION AS CAUSE OF INEQUALITY}


The discussion regarding the Brazilian wage-gap needs to focus on discriminatory theories. Because women's educational levels and productivity are as high as men, a large part of the gender difference in earnings is unexplained and many have argued that it is attributed to active discrimination against women (GIUBERTI and MENEZES-FILHO, 2005; MADALOZZO, 2010; LOVELL, 2000; LOUREIRO et al, 2004). Already in studies done in the 1990s, it was suggested that the gender wage-gap in Brazil was related in a larger extent to market discrimination rather than solely on individual characteristics (BARROS et al 1995). One author explains discriminatory in the Brazilian labour market as follow: 'if one takes into account gender differences in the occupational structure, educational attainment, and age distribution, the wage gap between gender increases. In other words, the discrimination by gender, as far as wages go, is even more pronounced than what one would find through a simple comparison between male and female wages' (BARROS et al 1995, p. 424). Similarly, others concluded that the causes of wage disparity are 'mainly accounted by discrimination factors' (BIDERMAN and STEFANI 2006, p.5). Only a small portion of wage differentials in the formal labour force can be attributed to differences between men and women in their capabilities - such as education or experience (BLAU and KAHN, 2016). For the most part, the wage gap appears to reflect discriminatory practices and social norms (KLAVEREN et al, 2009; KASSOUF and SILVA, 2000). 'When both have the same characteristics, men are better paid then women.' (MADALOZZO 2010, p.166).

In the field of economics, some studies investigated the impact of concentrated trade and financial liberalization in the early 1990s, and the subsequent impact of price stabilization, which took place following the introduction of the Real Plan in 1994 (LOUREIRO et al, 2004). The results suggest that the consolidation of the liberalization of the economy as well as macroeconomic stabilization contributed to increase the intensity of discrimination in Brazil (LOUREIRO et al, 2004, p. 141). A 2013 World Bank report considers a hypothetical set of anti-discrimination laws aimed at promoting equal pay between men and women (WORLD BANK, 2013). The model illustrated the impacts of an 'equal work, equal pay' policy on raising economic growth. In the long run, a reduction in gender bias leads to an increase of Brazil's annual gross domestic product growth rate (WORLD BANK, 2013). Eliminating the gap in the rates of employment between men and women would add $\mathrm{R} \$ 382$ billion to the country's economy, or 3.3 per cent of GDP (ILO, 2017). 
Investments in infrastructure and cash conditional transfers such as Bolsa Família may also enable greater gender equality. World Bank economists argue that poor access to core infrastructure services forces women to allocate a large fraction of their available time to family chores (AGÉNOR and CANUTO 2013). As a result, they have less time available to take care of their children, further their education, and occupy formal sector jobs. More and better access to rural roads, water, power grids, and other services would reduce mothers' time spent in household chores and raise time allocated to market work. Improved access to infrastructure services may free women's time in such a way that they could devote more time to building their own human capital. With improved access to water, transport, and electricity, women are able to spend less time on household chores - and become freer to study and find a job (WORLD BANK, 2013). Calculations simulating the effects of a budget-neutral increase in government spending on infrastructure investment, from its current value of about 2.1 per cent of GDP to 3.1 per cent, suggest that this policy could add between 0.5 and 0.9 percentage points to Brazil's annual rate of output growth, once direct and indirect effects - most notably through changes in women's time allocation and their bargaining power over family resources - are accounted for (AGENOR and CANUTO, 2013).

Gender inequality and wage gap is also related to double working hours and the need to reconcile work and family life. (TAMARINDO DA ROCHA and WEISHAUPT PRONI, 2018). Studies suggest that the probability of female participation in the labour market diminishes the higher the number of children (LOUREIRO et al, 2004, p. 141). Brazilian women, even those working full time, continue to bear the brunt of time allocated to family chores. In 2008, women devoted an average of 25.1 hours per week to caring for their families and housekeeping, whereas men devoted an average of only 10 hours per week to such tasks (BRUSCHINI, 2007). Most women remain under a 'double working day' because they are socially seen as responsible for the care of children, the elderly, and people with disabilities. In addition, often women are discriminated against because of the difficulty of reconciling work and family life (BLOFIELD and MARTÍNEZ, 2014). This is especially true in rural areas. Even with the growing participation of women in the public labour market, the number of employed women is eminently urban. A great part of women's activities in rural areas are intertwined with domestic chores and the real contribution of rural women to the production and family income is misinterpreted. Government policies have been addressing the needs of mothers, providing health care before and during pregnancy and at birth, and childcare and education, 
but more needs to be done. In Brazil, mothers are entitled to maternity leave for a maximum of six months - paternity leave spans only 20 days. Brazil could consider a model of "parental leave' based on the right to leave shared by both parents instead than maternity leave only. This is to ensure that both parents share child-rearing responsibilities, thus allowing women to return to work. This also affects hiring opportunities for women. Brazil prohibits gender discrimination in job opportunities, but issues remain - for example it is not uncommon for a prospective employers to ask a woman candidate about her marital status before hiring her (TAVARES, 2017). Instead, with a shared parental leave the burden of child rearing would affect women less at the time of hiring. The first chapter of the National Plans of Policy for Women 2013-2015 titled 'Equality in the labour market and financial autonomy' prescribed several concrete actions to be implemented by different government sectors addressing specific needs of women in rural areas, mothers, particularly health care before and during pregnancy and at birth, as well as childcare and education. It included for example: technical assistance and rural extension services, access to funding and credit, support to entrepreneurship, associations and cooperatives and to product trading; offering of public facilities and increase of free time with construction of day-care centres, nursery schools, universalization of maternity leave and extension of paternity leave, promotion of the culture of sharing household tasks between men and women; formalization of domestic workers so they have the same rights established in the Consolidation of Labour Laws for workers; and protection and social security to value unpaid domestic work, assuring the right to pension for low income housewives and extend the registrations of women in the social security system. To date tough, most of those policies have not been implemented.

With more women joining the workforce, the roles of men and women are being reshaped, enabling additional professional occupations for women and altering the social and family structures in society (MARQUES, 2005). But despite such new social image and the labour legislation in force, many women continue to suffer discrimination in the Brazilian labour market, due to the prevalence of a patriarchal culture (MACHADO, 2000; CORREIA BARBOSA et al. 2011). For women who are able to access the corporate world, discriminatory mechanisms persist. 


\section{THE ROLE OF THE PRIVATE SECTOR}

Brazil has not implemented yet enough policies that specifically target the private sector and addresses its important role in both sustaining and tackling gender discrimination. As Labour Law evolved from protecting women to guaranteeing equal treatment in the workplace (NOVAIS, 2005), at the same time public institutions for the defence of rights - such as the Ministry of Labour and Labour Courts - began to apply greater rigor in the investigation and judgment of the proceedings related to the matter. The Federal Government started to adopt equity promotion programmes that were reinforced with the creation of the Secretariat for Public Policies for Women. Special focus was placed on the public administration and large corporations. A few parliamentarians have tried to pass legislation to bridge the gender gap the labour market, but none of them has succeeded so far. A bill proposed in 2009, for example, mandates equal pay and the creation of a gender equality commission in every Brazilian company. But the Chamber of Deputies never voted it. On 13 March 2019, the Senate approved a bill proposal that provides a fine for employers who do not to pay the same salary to men and women performing the same tasks. According to the proposal, which seeks to amend the Consolidation of Labour Laws, a company that fails to comply with the rule will be fined for twice the amount of the verified salary difference to compensate the victim of discrimination. ${ }^{9}$

As mentioned above, most of the policies recommended by the National Plan for Women's Policies focus on women in rural areas, on informal employment and on domestic workers. Policies that deal with formal employment - such as the insertion and permanency in formal employment and in management positions, and the encouragement to professional qualification - have an emphasis in training and education for the public sector. In order to be effective, however, those policies should be implemented by the different government actors in cooperation with the private sector. Those actions could include offering of vocational courses, campaigns for the valorisation of women's work, promotion of women's insertion in the labour market, and wage equality.

In view of the legal and social repercussion of equity between men and women, a significant increase in lawsuits denouncing abuses, harassment and inequalities in

\footnotetext{
${ }^{9}$ Projeto de Lei do Senado ${ }^{\circ} 88$, de 2015
} 
remuneration, pressure from government institutions, media coverage, and trade unions militancy, a cultural change in the corporate world is begging to take place. As the social image of large corporations became central to their marketing strategy, it is becoming necessary for corporations to demonstrate a 'politically correct' stance towards shareholders and consumers (TAMARINDO DA ROCHA and WEISHAUPT PRONI, 2018). Thus, in a variety of sectors, leading companies are now including valuing diversity and promoting equity in their 'corporate social responsibility' (CSR) programmes (OBSERVATÓRIO SOCIAL, 2004; INSTITUTO ETHOS, 2007). Including women's rights in a corporation's CSR policy, however, is not the same than ensuring that women's rights are not violated and that they are not discriminated against. In the early 2000s, as a more comprehensive model of corporate social responsibility, which included a new relationship between the company and its employees, spread throughout Brazil, the trade union position on gender issues changed. The most combative unions intensified the requirement of compliance with the code of conduct in companies, encouraging their affiliates to report cases of discrimination (OBSERVATÓRIO SOCIAL, 2004).

A pro-gender equity programme initiative by the Secretariat of Public Policies for Women has been partially successful. The Pro-Equity Gender and Race Program, created in 2005 , sought the adhesion of companies that value the promotion of equality between women and men at work. The programme awards the Pro-Equity Race and Gender Seal to public and private companies. Of the 16 companies that joined it in the first edition (2005/2006), 11 were eligible for the 'pro-equity seal', which acknowledges businesses committed to ensuring equal pay and opportunities for all. By 2015, the 68 organizations enrolled in the programme employing around 1 million workers in Brazil (TAMARINDO DA ROCHA and WEISHAUPT PRONI, 2018). In the fourth edition, which was carried out between 2011 and 2012, 81 companies opted-in. Yet they are a minority among Brazil's businesses.

In 2015, only 28.2 per cent of the 500 largest companies operating in Brazil adopted policies to promote equal opportunities for men and women - for example, programmes for hiring women, goals for female participation in management positions, qualification to hold management positions, reduction of wage inequality, and reconciliation of work and family (INSTITUTO ETHOS, 2015). A survey conducted by the Fundação Getulio Vargas of Sao Paulo Law School in 2017 across Brazilian multinational corporations found that some sectors (particularly the consumer goods sector) have greater number of practices and policies designed to promote gender equality compared to others (the service sector had the lowest score) (FGV, 
2018). But the study also found that this does not necessarily entail a proportionally higher number of women in leadership positions. Among the 500 largest companies in Brazil, the percentage of women performing executive, managerial and supervisory functions increased, but the vast majority of these positions still remain occupied by men (INSTITUTO ETHOS, 2015). There is a mismatch between the emphatic discourse contained in sustainability reports (the term that replaced 'corporate social responsibility') and the results obtained in promoting equity (TAMARINDO DA ROCHA and WEISHAUPT PRONI, 2018).

The fight against gender discrimination brought about by the evolution of labour legislation is fundamental for valorising the female labour force, but has not been able to eliminate the differences in terms career advancement and pay for men and women, particularly in large companies (TAMARINDO DA ROCHA and WEISHAUPT PRONI, 2018). Unequal contractual pay for men and women in large corporations is apparent: overall, female employees earned 21.5 per cent less than male employees in 2015 (TAMARINDO DA ROCHA and WEISHAUPT PRONI, 2018). The wage gap between men and women who hold managerial positions in large companies is even more significant: women receive the equivalent of 61.6 per cent of men's average hourly wage (TAMARINDO DA ROCHA and WEISHAUPT PRONI, 2018).

Women rarely reach the highest hierarchical positions in large corporations - a phenomenon known as the 'glass ceiling', an imaginary barrier that prevents women from having career and promotion opportunities (MADALOZZO, 2011; STEIL, 1997; LAZZARETTI et al, 2013). This barrier is rooted in culture, society, and internalized psychological factors (BOLAT et al., 2011). In large companies, the participation of women in managerial positions was only 16.8 per cent in 2015. Because management positions are inherently male environments, men choose CEOs that represent them (MANDALOZZO 2011). The phenomenon of the 'second glass ceiling' refers to an invisible barrier proven by the negligible presence of female presidents in boards of directors - women occupy only 7 per cent of boards (IBGE, 2015) Women are still rarely sought for board roles, despite evidence showing that greater female participation in boards of directors positively contributes to various corporate management and organizational aspects - boards with more women are more active in decision-making and gender diversity among board members lead to more creative and innovative decisions (LAZZARETTI et al, 2013). The government has passed quota laws to increase female participation in boards. Senate Bill No. 112 of 2010 proposes a minimum 
percentage of women in the boards of directors of state-owned companies and companies with shared public and private ownership. It sets forth a progressive implementation schedule that foresees that a minimum proportion of 40 per cent women in these boards by 2022 . There is, however, no de facto quota of female representation in executive boards of private corporations (TAVARES, 2017).

Despite initiatives to promote gender equity in the corporate sector, advances are slow. For large companies to profoundly change their organizational culture would require a joint effort by the government, companies, unions, and CSOs. Legal requirements and other mandatory means may be necessary to achieve these changes - this task cannot be left to voluntary initiatives, such as CSR and sustainability policies, alone.

\section{CONCLUSION}

Gender inequality is rooted in cultural and social norms in Brazil. Despite women enjoying greater legal protection and having gained greater economic autonomy, gender inequalities still persist in the labour market. Brazilian women are still discriminated in their employment opportunities, wages, and career advancement and continue to bear the brunt of time allocated to family chore. A woman's hour of work is still worth a fifth less than that of a man in Brazil. Rather than mirroring differences such as education or experience, the wage gap appears to reflect discriminatory practices and social norms. Although slowing down, the gender inequality problem seems to be far from being solved in Brazil. Since equal rights between men and women were affirmed in the Federal Constitution of 1988 a number of laws have been passed to address gender discrimination. Equality in this area requires, however, more than a legal framework (TAMARINDO DA ROCHA and WEISHAUPT PRONI, 2018).

In August 2018, a group of UN human rights experts stated their 'regret that efforts in relation to targeted policies addressing systemic discrimination against women have not been sustained' (UN OHCHR 2018). Along with other members of the G-20, Brazil's government has committed to reduce gender inequality within the workforce by 25 per cent by 2025 and, as part of the Sustainable Development Goals set by the UN, to achieve equal pay by 2030 (MINISTÉRIO DAS RELAÇÕES EXTERIORES, 2017). To get there, Brazil's government should create systems that require employers to reveal salary information, ensure that employers comply with the law that forbids gender discrimination in the workplace, and 
strengthen legal channels for women to claim their rights under equal employment laws (HRW, 2018). Affirmative action measures have arisen in Brazil as major importance instruments to fight discrimination; they have become important tools to achieve the right to equal treatment. Yet there has been limited effort to quantify the impacts of gender-based policies on gender inequality in the labour market as well as economic growth in Brazil. Even though inequality has been diminishing, new affirmative action measures are necessary to guarantee women and men are treated equally in the workplace and earn the same. The challenge is to eliminate inequalities that restrict women's professional opportunities and which are reflected in the selection process, salary, working conditions, and career. To combat this type of discrimination, it is essential that there be political will for the adoption of affirmative action programmes (BARROS, 2010).

The promotion of gender equity within enterprises depends also on the adoption of effective strategies in the private sector. Public policies have a limited range of influence and are not capable of inducing real changes in the private sector. Even when a union denounces the recurrence of wage differentials between men and women, this hardly generates a corrective action (TAMARINDO DA ROCHA and WEISHAUPT PRONI, 2018). In general, large corporations respect women's protection legislation and often increase benefits through collective bargaining. Yet, this has not been enough to eliminate the sexual division of labour that prevails in corporations, nor to guarantee equal pay or equal opportunity to achieve positions of command in these organizations (TAMARINDO DA ROCHA and WEISHAUPT PRONI, 2018). There have been significant advances in corporate gender policies, but the commitments undertaken are far from producing satisfactory results. To be effective, corporate gender empowerment programmes should include actions to reconcile work and family life so to enabling more women to assume leadership roles. This cultural change within companies can not be imposed directly by the government, but it arises as a necessity for economic competition: programmes aimed at attracting and retaining highly qualified women are weapons in the competition for talent professionals, essential in the competitive strategy in emerging markets (HEWLETT and RASHID, 2011).

\section{REFERENCES}

AGÊNCIA IBGE. 2013. 'Estatísticas de gênero: responsabilidade por afazeres afeta inserção das mulheres no mercado de trabalho'. https://agenciadenoticias.ibge.gov.br/agencia-sala-de- 
imprensa/2013-agencia-de-noticias/releases/20232-estatisticas-de-genero-responsabilidadepor-afazeres-afeta-insercao-das-mulheres-no-mercado-de-trabalho.html

AGÊNCIA IBGE. 2018. 'Estatísticas de gênero: responsabilidade por afazeres afeta inserção das mulheres no mercado de trabalho'. https://agenciadenoticias.ibge.gov.br/agencia-sala-deimprensa/2013-agencia-de-noticias/releases/20232-estatisticas-de-genero-responsabilidadepor-afazeres-afeta-insercao-das-mulheres-no-mercado-de-trabalho.html

AGÊNCIA IBGE. 2019 'Diferença cai em sete anos, mas mulheres ainda ganham 20,5\% menos que homens' https://agenciadenoticias.ibge.gov.br/agencia-noticias/2012-agencia-denoticias/noticias/23924-diferenca-cai-em-sete-anos-mas-mulheres-ainda-ganham-20-5menos-que-homens

AGÉNOR, Pierre-Richard, and CANUTO, Otaviano. 2012a. 'Access to Infrastructure and Women's Time Allocation: Evidence and a Framework for Policy Analysis.' Policy Paper No. 45 .

AGÉNOR, Pierre-Richard, and CANUTO, Otaviano. 2012b. 'Measuring the Effect of GenderBased Policies on Economic Growth.' Economic Premise 85, World Bank, Washington, DC.

AGÉNOR, Pierre-Richard, and CANUTO, Otaviano. 2013a. 'Gender Inequality and Economic Growth in Brazil: A Long-Run Analysis. Policy Research Working Paper No. 6348. World Bank.

AGÉNOR, Pierre-Richard and CANUTO, Otaviano. 2013b. 'Gender Equality and Economic Growth in Brazil'. World Bank.

ARAÚJO, Clara. 2011. 'As Mulheres e o Poder Político - Desafios para a Democracia nas Próximas Décadas' in: BRASTED, Leila Linhares; PITANGUY, Jacqueline. O Progresso das Mulheres no Brasil 2003-2010. Rio de Janeiro: CEPIA; Brasília: ONU Mulheres.

BARROS, Alice Monteiro de. 1995. A mulher e o direito do trabalho. São Paulo: LTr.

BARROS, Alice Monteiro de. 2010. 'Discriminação no emprego por motivo de sexo'. In: RENAULT, Luiz Otávio Linhares; VIANA, Márcio Túlio; CANTELLI, Paula Oliveira. Discriminação. 2.ed. São Paulo: LTr.

BARROS, Ricardo, RAMOS, Lauro, SANTOS, Eleonora. (1995). 'Gender differences in Brazilian labor markets' in Investment in women's capital University of Chicago Press, 380425.

BIDERMAN, Ciro; GUIMARÃES, Nadya Araujo. 2004. 'Na ante-sala da discriminação: o preço dos atributos de sexo e cor no Brasil (1989-1999)'. Revista Estudos Feministas. Florianópolis, v. 12, n. 2, p. 177-200.

BIDERMAN, Ciro and STEFANI, Patricia. (2006). 'Returns to Education and Wage Differentials in Brazil: A Quantile Approach’ Economics Bulletin, Vol. 9, No. 1 pp. 1-6. 
BIRDSALL, Nancy, and FOX, M. Louise. 1985. 'Why males earn more: location and training of Brazilian school teachers'. Economic Development and Cultural Change. Vol. 33 No. 3. 533-556.

BLAU, Francine D. and KAHN, Lawrence M. JANUARY 2016. 'The Gender Wage Gap: Extent, Trends, and Explanations'. IZA Discussion Paper No. 9656.

BLOFIELD, Merike, and MARTÍNEZ, Juliana. 2014. 'Trabajo, familia y cambios en la política pública en América Latina: equidad, maternalismo y corresponsabilidad'. Revista Cepal, n. 114. p. 107-125.

BOLAT, Tamer, BOLAT, Oya Inci and KILIÇ, Taskin. (2011). 'Career self-efficacy and glass ceiling: moderating effect of work-related masculinity values' of Interdisciplinary Journal Contemporary Research in Business, Vol. 2 No. 10, pp. 56-68.

BRASTED, Leila Linhares; PITANGUY, Jacqueline (Org.). O Progresso das Mulheres no Brasil 2003-2010. Rio de Janeiro: CEPIA; Brasília: ONU Mulheres.

BREST, Paul; LEVINSON, Sanford; BALKIN, J. M.; AMAR, Akhil Reed. 2000. Processes of Constitutional Decisionmaking. 4 ed., Gaithersburg: Aspen.

BRUSCHINI, Cristina. 2000. 'Gênero e trabalho no Brasil: novas conquistas ou persistência da discriminação?'. In: ROCHA, Maria Isabel Baltar da. Trabalho e gênero: mudanças, permanências e desafios. São Paulo: Editora. p. 13-58.

BRUSCHINI, Cristina. 2007. 'Work and Gender in Brazil in the Last Ten Years'. Cadernos de Pesquisa 37. 537-572.

BRUSCHINI, Cristina; LOMBARDI, Maria Rosa; MERCADO, Cristiano Miglioranza; RICOLDI, Arlene. 2011. Trabalho, Renda e Políticas Sociais: Avanços e Desafios. In: BRASTED, Leila Linhares; PITANGUY, Jacqueline (Org.). O Progresso das Mulheres no Brasil 2003-2010. Rio de Janeiro: CEPIA; Brasília: ONU Mulheres.

CACCIAMALI, Maria Cristina; TATEI, Fábio; ROSALINO, Jackson William. 2009. 'Estreitamento dos diferenciais de salários e aumento do grau de discriminação: limites da mensuração padrão?'. Planejamento e Políticas Públicas, n. 33, p. 195-222.

CALIL, Léa Elisa Silingowsch. 2000. História do direito do trabalho da mulher: aspectos histórico-sociológicos do início da república ao final deste século. São Paulo: LTr.

CANUTO, Otaviano. 3 July 2013. World Bank. 'Gender Equality Pays Off in Brazil'. http://blogs.worldbank.org/growth/gender-equality-pays-brazil

CAVALCANTI, Stela Valéria. 2006. 'Igualdade, Discriminação Positiva e Políticas Públicas para Mulheres no Brasil'. Revista do Mestrado em Direito da Universidade Federal de Alagoas. Ano 2, n. 2. 345-379.

CIA (Central Intelligence Agency). 2017. The World Factbook. 
https://www.cia.gov/library/publications/the-world-factbook/rankorder/2172rank.html

CORREIA BARBOSA, Milka Alves; NEY MATOS Fátima Regina, FERREIRA DOS SANTOS Ana Paula; BATISTA ALMEIDA Ana Márcia. (2011). 'Mulheres e Patriarcado: Dependência e Submissão nas Casas de Farinha do Agreste Alagoano', Encontro Nacional Da Associacão Dos Programas De Pós-Graduacão Em Administracão, Vol. 35.

DIAS, Maria Berenice. 1998. 'Ações Afirmativas: uma solução para a desigualdade'. Revista Del Rey. No. 4. 26-43.

ELSEVIER. 2018. 'Gender in the Global Research Landscape'.

https://www.elsevier.com/_data/assets/pdf_file/0008/265661/ElsevierGenderReport_final_fo r-web.pdf

FRY, Peter; MAGGIE, Yvonne. 2004. 'Cotas raciais: construindo um país dividido?'. Econômica: Revista da Pós-Graduação em Economia da UFF, Niterói. V. 6, n. 1. 153-161.

FUNDAÇÃO GETULIO VARGAS (FGV). 10 January 2018. 'Study maps gender equality within companies in Brazil'

https://portal.fgv.br/en/news/study-maps-gender-equality-within-companies-brazil

GARCIA, L., ÑOPO, H. and SALARDI, P. 2009. 'Gender and racial wage gaps in Brazil 19962006: evidence using a matching comparisons approach'. Working Paper No. 681. InterAmerican Development Bank. Washington, DC.

GIUBERTI, A. AND MENEZES-FILHO, N. (2005). "Discriminação de rendimentos por gênero: Uma comparação entre o Brasil e os Estados Unidos". Economia Aplicada, Vol 9, No 3, pp. 369-383.

GUIMARÃES, Nadya Araujo. 2002. 'Os desafios da equidade: reestruturação e desigualdades de gênero e raça no Brasil'. Cadernos Pagu, n. 17-18, p. 237-266.

HEWLETT, Sylvia Ann and RASHID, Ripa. 2011. Winning the war for talent in emerging markets: why women are the solution. Boston: Harvard Business Review Press.

HRW (Human Rights Watch). 8 March 2018. 'Working for Less in Brazil'. https://www.hrw.org/news/2018/03/08/working-less-brazil

IBGC (2011), 'Mulheres nos Conselhos (2009)', Instituto Brasileiro de Governança Corporativa, www.ibgc.org.br/Pesquisas.aspx

ILO (International Labor Organization). 4 June 2017. 'Reduzir a desigualdade de gênero beneficiaria as mulheres, a sociedade e a economia'.

http://www.ilo.org/brasilia/noticias/WCMS_558360/lang--pt/index.htm

INEP/MEC (Instituto Nacional de Estudos e Pesquisas Educacionais Ansio Teixeira/MEC). 2004. 'O desafio de uma educação de qualidade para todos: educação no Brasil - 1990-2000'. Brasília-DF. 
INSTITUTO ETHOS. 2007. Indicadores Ethos de responsabilidade social empresarial. São Paulo: Ethos.

INSTITUTO ETHOS. 2015. Perfil social, racial e de gênero das 500 maiores empresas do Brasil e suas ações afirmativas. São Paulo: Ethos.

KASSOUF, Ana Lúcia and VIEIRA SILVA, Nency de Deus. (2000). 'Mercados de trabalho formal e informal: Uma análise da discriminação e da segmentação'. Nova Economia, Vol 10, No 1 pp. 41-77.

KAUFMANN MENEZES, Roberta Fragoso. 2007. Ações Afirmativas à brasileira: necessidade ou mito? uma análise histórico-jurídico-comparativa do negro nos Estados Unidos da América e no Brasil. Porto Alegre: Livraria do advogado.

KNAPP, Eduardo. 2015. 'Dois séculos separam mulheres e homens da igualdade no Brasil'. Jornal Folha de São Paulo.

http://www1.folha.uol.com.br/asmais/2015/09/1675183-no-ritmo-atual-fim-da-desigualdadeentre-homens-e-mulheres-demoraria-240-anos.shtml

LAVINAS, Lena. 1996. 'Aumentando a competitividade das mulheres no mercado de trabalho'. Revista Estudos Feministas, v. 4, n. 1, p. 171-182.

LAZZARETTI, Kellen; KLEINUBING GODOI, Christiane; PARODI OLIVEIRA, Silvio Camilo and MARCON, Rosilene. 2013. 'Gender diversity in the boards of directors of Brazilian businesses' Gender in Management: An International Journal Vol. 28 No. 2, pp. 94-110.

LEITE, Marcia de Paula and SALAS, Carlos. 2014. 'Trabalho e desigualdades sob um novo modelo de desenvolvimento'. Tempo Social, USP, v. 26, n. 1, p. 87-100.

LEONE, Eugenia Troncoso. 2015. 'O avanço das mulheres na expansão do mercado de trabalho após 2003'. Carta Social e do Trabalho, Cesit, n. 29, p. 2-21.

LEONE, Eugenia Troncoso; TEIXEIRA, Marilane Oliveira. 2013. 'As mulheres no mercado de trabalho e na organização sindical'. Carta Social e do Trabalho, Cesit, n. 21, p. 2-22.

LIU, Wenjun, Tomokazu NOMURA and Shoji NISHIJIMA. 2016. 'Gender discrimination and firms' profit: evidence from Brazil'. Emerald Group Publishing.

LOPES, Cristiane Maria Sbalqueiro. 2006. 'Direito do trabalho da mulher: da proteção à promoção' Cadernos Pagu, n. 26, p. 405-430.

LOPES RIBEIRO, Lilian, and EMERSON Marinho. April 2012. 'Time Poverty in Brazil: Measurement and Analysis of its Determinants'. Estudos Econômicos 42. 285-306.

LOUREIRO, Paulo R.A., Francisco GALRÃO CARNEIRO and Adolfo SACHSIDA. 2004. 'Race and gender discrimination in the labour market: an urban and rural sector analysis for Brazil'. Journal of Economic Studies. Vol. 31 No. 2. 129-143. 
LOVELL, Peggy A. 1993. 'Development and discrimination in Brazil'. Development and Change. Vol. 24. 83-101.

LOVELL, Peggy A. 2000. 'Race, gender and regional labour market inequalities in Brazil'. Review of Social Economy. Vol. 58 No. 3. 277-293.

LUPICA, Carina. 2015. 'Instituciones laborales y políticas de empleo: avances estratégicos y desafíos pendientes para la autonomía económica de las mujeres'. Cepal - Repositorio Digital. Chile: Cepal. Serie Asunto de Género, n. 125.

MACHADO, Lia Zanotta. 2000. 'Perspectivas em confronto: relações de gênero ou patriarcado contemporâneo?’. Brasília: UnB. Série Antropologia n. 284.

MADALOZZO, R. 2010. 'Occupational segregation and the gender wage gap in Brazil: an empirical analysis'. Economia Aplicada. Vol. 14 No. 2. 147-168.

MADALOZZO, R. (2011), "CEOs e Composic ,ão do Conselho de Administrac, a o: a falta de identificac,a a pode ser motivo para existe^ncia de teto de vidro para mulheres no Brasil?", RAC, Vol. 15 No. 1, pp. 126-37

MARQUES, Elisabeth Kurtz. (2005), 'Mulheres ocupadas em cargos de direcão: mudancãs e permanências no mercado de trabalho na RMPA", Mulher e Trabalho, Vol. 5, pp. 133-43.

MÈLIN-SOUCRAMANIEN, Ferdinand. 1997. Le Principle d'égalité dans la Jurisprudence du Conseil Constitucionnel. Paris: Economica.

MELLO, Celso Antônio Bandeira de. 1998. O conteúdo jurídico do princípio da igualdade. 3. ed., 4. tir. São Paulo: Malheiros.

MELLO, Marco Aurélio Mendes de Farias. 2001. Ótica Constitucional - a Igualdade e as Ações Afirmativas In: Discriminação e Sistema Legal Brasileiro - Seminário Nacional em comemoração do Dia do Zumbi dos Palmares. Anais Tribunal Superior do Trabalho: Brasília.

MINISTÉRIO DAS RELAÇÕES EXTERIORES. 8 July 2017. 'Declaração dos Lideres do G20 - Moldando um Mundo Interconectado'. Nota 221.

http://www.itamaraty.gov.br/pt-BR/notas-a-imprensa/16800-declaracao-dos-lideres-do-g20moldando-um-mundo-interconectado

MOEHLECKE, Sabrina. 2002. 'Ação Afirmativa: história e debates no Brasil'. Cadernos de Pesquisa. N. 117. 197-217.

NEVES, Magda de A. 2000. 'Reestruturação produtiva, qualificação e relações de gênero'. In: ROCHA, Maria Isabel Baltar da. Trabalho e gênero: mudanças, permanências e desafios. São Paulo: Editora 34.

NOMURA, Tomokazu. 2010. 'On the male-female wage differentials in Brazil: intraoccupational differentials and occupational segregation'. Ajia Keizai. Vol. 51 No. 12. 2-21 
ÑOPO, Hugo. 2012. 'New Century, Old Disparities: Gender and Ethnic Earnings Gaps in Latin America and the Caribbean'. Inter-American Development Bank and World Bank. Washington, DC.

NOVAIS, Denise Pasello Valente. 2005. Discriminação da mulher e Direito do Trabalho: da proteção à promoção da igualdade. São Paulo: LTr.

OBSERVATÓRIO SOCIAL. 2004. 'A mulher no mercado de trabalho'. Observatório Nacional em Revista, n. 5.

O GLOBO. 19 February 2018. 'Mulheres ainda ganham 15\% menos do que os homens no mercado formal'. https://oglobo.globo.com/economia/mulheres-ainda-ganham-15-menos-doque-os-homens-no-mercado-formal-22410924

OECD. June 2017. 'How does BRAZIL compare? Employment Outlook 2017'. https://www.oecd.org/brazil/Employment-Outlook-Brazil-EN.pdf

PIOVESAN, Flávia. 2005. 'Ações Afirmativas da Perspectiva dos Direitos Humanos'. Cadernos de Pesquisa. V. 35, n. 124. 43-55.

PRESIDÊNCIA DA REPÚBLICA DO BRASIL. (2013). Secretaria de Políticas para as Mulheres. Plano Nacional de Políticas para as Mulheres. Brasília: Secretaria de Políticas para as Mulheres

http://www.spm.gov.br/assuntos/pnpm/publicacoes/pnpm-2013-2015-em22ago13.pdf.

PRONI, Marcelo Weishaupt and LEONE, Eugenia Troncoso. 2013. 'Desigualdades de gênero e raça no mercado de trabalho brasileiro'. In: KREIN, José Dari et al. Regulação do trabalho e instituições públicas. São Paulo: Fundação Perseu Abramo. v. 2.

RIFIOTIS, Theophilos. 2004. 'As delegacias especiais de proteção à mulher no Brasil e a «judiciarização» dos conflitos conjugais’. Sociedade e Estado, Brasília. V. 19, n. 1. 53-94.

SIMS, Shannon. 2017. Forbes. 'Surprising New Study: Brazil Now a Global Leader in Gender Equality in Science'

https://www.forbes.com/sites/shannonsims/2017/03/08/surprising-new-study-brazil-now-aglobal-leader-in-gender-equality-in-science/\#765d5906f448

STEIL, Andrea Valéria. 1997. 'Organizações, gênero e posição hierárquica - compreendendo o fenômeno do teto de vidro'. Revista de Administração. v. 32, n. 3, p. 62-69.

TAMARINDO DA ROCHA WEISHAUPT PRONI, Thaíssa and WEISHAUPT PRONI, Marcelo. 2018. 'Discriminação de gênero em grandes empresas no Brasil'. Revista Estudos Feminista, vol. 26 no.1.

TAVARES, Paula. 2017. 'How Does Brazilian Law See Women?'. 20 March 2017. http://blogs.worldbank.org/latinamerica/how-does-brazilian-law-see-women 
UN WOMEN. 2017. Women in Politics 2017.

http://www.unwomen.org/media/headquarters/attachments/sections/library/publications/2017/ femmesenpolitique_2017_english_web.pdf?la=en\&vs=1123

UNDP. 2016. 'Gender Inequality Index (GII)'. http://hdr.undp.org/en/indicators/68606

URIBE, Gustavo. 2018. 'Temer demite ministra dos Direitos Humanos'. Folha de S. Paulo. https://www1.folha.uol.com.br/poder/2018/02/ministra-dos-direitos-humanos-pede-demissaoa-temer.shtml

VAN KLAVEREN, Maarten, Kea TIJDENS, Melanie HUGHIE-WILLIAMS, and Nuria RAMOS MARTIN. 2009. 'An Overview of Women's Work and Employment in Brazil'.

WAJNMAN, Simone and RIOS NETO, Eduardo. 2000. 'Women's participation in the labor market in Brazil: elements for projecting levels and trends'. Brazilian Journal of Population Studies. No. 2. 41-54.

WORLD BANK. 22 February 2013. 'Women at Work, Good for them and the Brazilian Economy'.

http://www.worldbank.org/en/news/feature/2013/02/22/Brazil-why-promoting-equal-pay-isgood-for-economy-job-market

WORLD BANK. 2017a. 'Firms with female participation in ownership'. https://data.worldbank.org/indicator/IC.FRM.FEMO.ZS

WORLD BANK. 2017b. 'Labor force, female'. https://data.worldbank.org/indicator/SL.TLF.TOTL.FE.ZS

WORLD ECONOMIC FORUM. 2017. GGI Index, Brazil. http://reports.weforum.org/pdf/ggi-2017/ggi_index_2017_BRA.pdf 